\title{
IMPACT OF MACA ADMINISTRATION ON THE CONCEPTION RATE AND REPRODUCTIVE PERFORMANCE OF RABBIT DOES OF DIFFERENT BREEDS.
}

\author{
T.M. El-Sheikh', A.A. Abuoghaba ${ }^{1}$, Kawther M.A. Ghaly ${ }^{2}$ and Marian Kh. Wadeaa ${ }^{3}$ \\ ${ }^{1}$ Department of Poultry Production, Faculty of Agriculture, Sohag University, Sohag, Egypt \\ ${ }^{2}$ Department of Animal and Poultry Production, Faculty of Agriculture, Minia University, Minia, Egypt \\ ${ }^{3}$ Department of Animal Production, Faculty of Agriculture, Beni Suef University, Beni Suef, Egypt
}

Corresponding Author: Prof Dr. Talaat Mostafa El-Sheikh; talaatm2@yahoo.com

(Received 8/10/2019, accepted 2/12/2019)

\section{SUMMARY}

$\mathrm{T}$ This work aimed to study the impact of Maca capsules administration on the conception rate and hormonal estimates of rabbit Does. Thirty six rabbit does, (12 V-line, 12 New Zealand white and 12 Bouscat), were divided equally into two equal groups 6 does per each. In the $1^{\text {st }}$ group, rabbits were fed a commercial breeder ration without any supplementation; while the $2^{\text {nd }}$ group was fed the commercial breeder ration and daily orally administered with $500 \mathrm{mg}$ Maca capsule/doe for one week before mating. All does in the treated group were re-administered with the same dose after three days from parturition (day per day) for one week, then re-mated directly during the $2^{\text {nd }}$ and $3^{\text {rd }}$ parties, respectively. The number of mating per conception (NMPC), Conception rated (CR \%), Gestation length $(\mathrm{Gl})$, luteinizing hormone ( $\mathrm{LH})$, follicle stimulating hormone (FSH), Estrogen and Progesterone hormone concentrations of rabbit does were measured. The obtained results indicated that there were no significant effect of Maca administration on the NMPC, CR, GL, LH, FSH and progesterone (P4) hormone concentrations in the different rabbit breeds. While the mean estrogen hormone concentration was significantly $(\mathrm{P} \leq 0.001)$ higher in NZW Does, followed by V-line. lower value was observed in Bouscat rabbit Does. Also, the estrogen hormone concentration of treated rabbit does was insignificantly higher, while no significant effect was found at the interaction between rabbit breed and maca treatment on NMPC, CR, GL, LH, FSH, estrogen and progesterone hormone concentrations. From the obtained findings, it could be concluded that the oral administration of rabbit does with maca capsules insignificantly influenced NMPC, CR, GL, LH, FSH, estrogen and progesterone hormone concentrations.

Keywords: rabbit does Maca administration, conception rate, and hormonal estimates

\section{INTRODUCTION}

Maca root is an adaptogenic herb that has been shown in studies to improve fertility in both men and women. It contains about 31 different minerals and 60 different phytonutrients, Maca is a nourishing food for the endocrine system, aiding the pituitary, adrenal, and thyroid glands. Maca has the ability to affect key hormones in both women and men without containing hormones itself Hethir Rodriguez (2007).

Maca has been scientifically researched for the use of increasing fertility since 1961 and has been shown to contain specific compounds called glucosinolates which can affect fertility for both men and women. These alkaloids are responsible for Maca's ability to support hormonal balance.

Yoshida et al., (2017) indicated that the Maca play an important role to promotes optimal functioning for both hypothalamus and pituitary, throughout the balance effects on FSH, estradiol and progesterone of women.

Studies have shown that men who use Maca may experience an increased libido and an increase in sperm health. In one study, maca was given to female and male rats and it was found that the females had multiple egg follicle maturation (important for ovulation), and the males had significantly higher sperm production and motility rates. Hethir Rodriguez (2007)

Hethir Rodriguez, (2007) found that in female rats taking maca, multiple egg follicles were able to successfully mature, which is important for ovulation and reproductive health. Maca improves sexual 


\section{El-Sheikh et al.}

performance without changing reproductive hormone levels (Gonzales et al., 2005). They added that Maca's had beneficial effects for sexual function due to its high concentration of proteins and vital nutrients. Chaco`n de popovicio et al., (1997) stated that, maca contains a chemical called pmethoxybenzyl isothiocyanates, which reputedly has aphrodisiac properties

Maca increased blood levels of progesterone in female mice because it contains saponins which play a very important role in sex hormones Saponins have been shown to normalize hormone secretion and have been used to treat sexual dysfunction (Arletti et al., 1999). Due to these actions, saponins are called adaptogens (Kropotov et al., 2001 and Kelly 2001). However, the mechanism of action for adaptogens has not been clarified (Kropotov et al., 2001). Therefore, the current study was conducted to evaluate the impact of treating rabbit Does with Maca in capsulated form on reproductive performance of rabbits, milk yield and hormonal secretion.

\section{MATERIALS AND METHODS}

This study was carried out at the research rabbit Farm, Poultry Production Department, Faculty of Agriculture Sohag University during the period from August 2017 to January, 2018, to investigate the effect of Maca administration on the NMPC, CR, GL, LH, FSH, estrogen and progesterone hormone concentrations of rabbit does.

\section{Experimental design:}

A total of 36 rabbit does V-line, New Zealand white and Bouscat, with 12 of each. Rabbits were divided equally into two equal groups; each of them included $6 \mathrm{~V}$-line, 6 Newzeland and 6 Bouscat and with 12 of each. Rabbits were divided equally into two equal groups; each of them included $6 \mathrm{~V}$-line , 6 Newzeland and 6 Bouscat In the $1^{\text {st }}$ group, rabbits were fed a commercial breeder ration without any supplementation, while the $2^{\text {nd }}$ group were fed the commercial breeder ration and orally administered with $500 \mathrm{mg}$ Maca capsules/doe/day for one week before mating. All does were re-administered with the same dose after three days from parturition for one week (day per day), then re-mated directly for the second and third parties.

\section{Housing the experimental rabbits:}

All does were individually housed in wire galvanized battery cages $(50 \mathrm{~cm} \mathrm{~L} \times 50 \mathrm{~cm} \mathrm{~W} \times 40 \mathrm{~cm} \mathrm{H})$ in open side house under the same managerial and hygienic conditions. They were daily exposed to All does were individually housed in wire galvanized battery cages $(50 \mathrm{~cm} \mathrm{~L} \times 50 \mathrm{~cm} \mathrm{~W} \times 40 \mathrm{~cm} \mathrm{H})$ in open side house under the same managerial and hygienic conditions. They were offered ad-libitum the feed and fresh tap water during the experimental period.

\section{Experimental diets:}

All does were fed on a basal commercial. . The basal diet contains $16.89 \%$ crude protein, $12.67 \%$ crude fiber, $2.99 \%$ fat, $0.63 \% \mathrm{Ca}$ and $2799 \mathrm{Kcal} / \mathrm{kg}$ digestible energy. Maca contains $10.2 \%$ crude protein, $59.0 \%$ carbohydrates, $2.20 \%$ fat, and 8.5\% fibers (Documenta Geigy., 1963).

\section{Climatic conditions:}

The interior ambient temperature $\left({ }^{\circ} \mathrm{C}\right)$ and relative humidity $(\%)$ were daily recorded in the rabbitry farm at 9.0AM and 13.0PM by using a thermo-hygrometer.

The temperature humidity index were calculated and recorded by the following equation according to Marai et al., (2002):

$\mathrm{THI}=\mathrm{db}^{\circ} \mathrm{C}-\left[(0.31-0.31 \mathrm{RH} / 100) \times\left(\mathrm{db}^{\circ} \mathrm{c}-14.4\right)\right]$

$\mathrm{THI}=$ Temperature humidity index, $\mathrm{db}^{\circ} \mathrm{C}=$ the ambient temperature, $\mathrm{RH}=$ the relative humidity $(\%)$.

Climatic conditions during the experimental periods are shown in table (1). 
Table (1). Average of ambient temparature $\left(\mathrm{AT} /{ }^{\circ} \mathrm{C}\right)$, relative humidity $(\mathrm{RH} / \%)$ and temperature humidity index (THI/units) during the experimental period

\begin{tabular}{|c|c|c|c|c|}
\hline Period & Date & $\mathrm{AT}\left({ }^{\circ} \mathrm{C}\right)$ & RH (\%) & THI (units) \\
\hline 1 & 15 Aug-12 Sep & 30.86 & 63.25 & 22.53 \\
\hline 2 & 12 Sep -10 Oct & 29.18 & 61.75 & 21.77 \\
\hline 3 & 10 Oct -7 Nov. & 28.92 & 61.75 & 21.64 \\
\hline 4 & 7Nov.- 5 Dec. & 25.63 & 57.50 & 20.15 \\
\hline 5 & 5 Dec. -2Jan. & 22.00 & 58.25 & 18.27 \\
\hline 6 & 2 Jan.- 30 Jan. & 18.63 & 58.25 & 16.55 \\
\hline
\end{tabular}

\section{Lighting programe}

All rabbits exposed to the same lighting programe according the natural day length. According the data in Table (2) which shows the length of every day during the experimental period, so the design light programe curve was as follow: The lighting program is continues light and dark cycles and is decreasing lighting programe. The light intensity was 5 Lux during the day light.

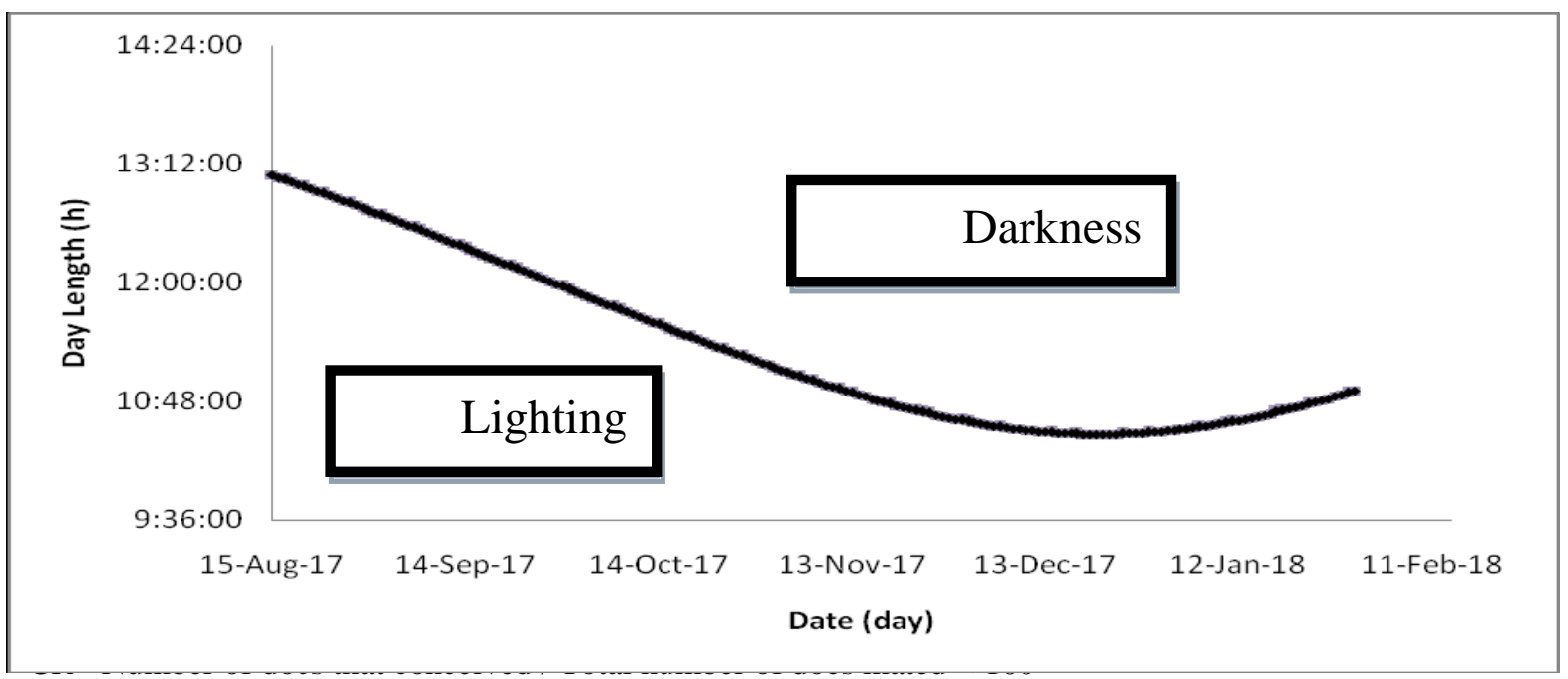

Figure (1): The length of every day during the experimental period,

\section{Blood constituents:}

Blood samples were collected at 11.0 am from the marginal ear vein per each doe in dry clean centrifuge tubes on the $7^{\text {th }}$ day of administration and $14^{\text {th }}$ day of kindling. Thereafter, blood serum was separated by centrifugation at $3000 \mathrm{rpm}$ for5minutes and kept in a deep freezer at $\left(-20^{\circ} \mathrm{C}\right)$ until analysis.

\section{Hormonal assay:}

The serum concentrations of LH, FSH and Estrogen hormones were determined at $7^{\text {th }}$ day from administration, while the concentration of progesterone hormone (P4) was determined at $14^{\text {th }}$ day from pregnancy. All hormones were determined according to the methods of TOSOH (close system) in smart laboratory.

\section{Statistical analysis:}

The obtained data were statistically analyzed by using GLM, produced by the statistical analysis systems (SAS, 2004). Duncan's new multiple ranges tests (Duncan, 1955) were used to determine significant differences between treatment means. The following linear model was applied: Eij $=\mu+B_{i}+$ $T_{j}+B_{i} T_{j}+e_{i j}$ 
Where; Yij= Observation measured, $\mu=$ Overall mean, $B_{i}=$ Effect of rabbit breed $(1,2$ and 3$), T j=$ Effect of Maca treatment $\left(\mathrm{j}=1\right.$ and 2), $\mathrm{BT}_{\mathrm{ij}}=$ Interaction between rabbit breed and Maca treatment, Eij= Random error component was normally distributed assumed.

\section{RESULTS AND DISCUSSIONS}

\section{Effect of rabbit breeds and maca treatment on NMPC, CR and GL:}

Results in Table (6) showed that the highest value of number of mating per conceptation (NMPC/times) was recorded in Bouscat rabbits the compared with NZW and V-line. The increased (NMPC/times) in the Bouscat rabbit may be due to the genetic differences between rabbits, therefore the the number of mating times to conceive required for fertilization in V-line rabbit was less than the other two breeds, and this reflects the ability of the high V-line to conceive. These results agree with those of Azoz and El-khaly (2005, 2006) and Gad Allah et al., (2005), who found that the number of services per conception of V-line rabbits was significantly lower than that of Bouscat or Baladi rabbit does .They attributed that the decreased number of services per conception associated with higher values of conception rate.

The highest value $(\mathrm{P} \leq 0.01)$ of conception rate $(\mathrm{CR} / \%)$ was recorded in $\mathrm{V}$-line rabbits, while the lowestr values were recorded in NZW and Bouscat rabbits. The achieved results disagreed with those of El-Hammady and Abdel-Kareem (2015), they found no significant differences in number of mating per conception (NMPC/times) and conception rate (CR/\%) among V-Line, NZW and Bouscat rabbit does. Data in Table (2), illustated that the gestation length (GL/day) for rabbits was insignificantly affected by rabbit breed, maca treatment and their interaction.

Referring to maca treatment, these data of table (2) showed that the means of NMPC (times), CR (\%) and GL (day) of different rabbit breeds were insignifcantly influenced by maca treatment. These results are in agreement with Ruiz-Luna et al., (2005), who reported that the gestation length in adult female mice were not influenced by Maca-treatment, which recorded similar results in different groups.

Effect of the interaction, there was no significant effect due to the interaction between rabbit breed and maca treatment on NMPC (times), CR (\%) and GL (day) of rabbit does.

Table (2). Effect of Maca treatment and rabbit breeds on NMPC (times), CR (\%) and GL (day) of rabbit does $(\mathrm{LSM} \pm \mathrm{SE})$.

\begin{tabular}{|c|c|c|c|c|}
\hline \multicolumn{2}{|l|}{ Items } & NMPC (times) & $\mathrm{CR}(\%)$ & GL (day) \\
\hline \multicolumn{5}{|c|}{ Effect of rabbit breed (B) } \\
\hline \multicolumn{2}{|l|}{ V-line } & $1.77^{\mathrm{b}} \pm 0.20$ & $70.16^{\mathrm{a}} \pm 6.90$ & $32.16 \pm 0.5$ \\
\hline \multicolumn{2}{|l|}{ NZW } & $2.21^{\mathrm{ab}} \pm 0.22$ & $54.55^{\mathrm{ab}} \pm 7.34$ & $31.83 \pm 0.5$ \\
\hline \multicolumn{2}{|l|}{ Bouscat } & $2.39^{\mathrm{a}} \pm 0.20$ & $54.45^{\mathrm{b}} \pm 6.29$ & $32.74 \pm 0.5$ \\
\hline \multicolumn{5}{|c|}{ Effect of maca treatment $(\mathrm{T})$} \\
\hline \multicolumn{2}{|l|}{ Control } & $2.12 \pm 0.17$ & $57.00 \pm 5.67$ & $31.78 \pm 0.4$ \\
\hline \multicolumn{2}{|c|}{ Treatment } & $2.15 \pm 0.17$ & $55.85 \pm 5.85$ & $32.70 \pm 0.4$ \\
\hline \multicolumn{5}{|c|}{ Effect of interaction $(\mathrm{B} \times \mathrm{T})$} \\
\hline \multirow{2}{*}{ V-line } & Control & $1.80 \pm 0.30$ & $70.00 \pm 10.41$ & $32.38 \pm 0.7$ \\
\hline & Treatment & $1.75 \pm 0.27$ & $70.31 \pm 9.47$ & $31.93 \pm 0.6$ \\
\hline \multirow{2}{*}{ NZW } & Control & $2.35 \pm 0.32$ & $50.00 \pm 10.50$ & $30.82 \pm 0.7$ \\
\hline & Treatment & $2.06 \pm 0.31$ & $59.38 \pm 10.43$ & $32.83 \pm 0.7$ \\
\hline \multirow{2}{*}{ Bouscat } & Control & $2.17 \pm 0.26$ & $52.78 \pm 8.55$ & $32.14 \pm 0.6$ \\
\hline & Treatment & $2.67 \pm 0.30$ & $36.76 \pm 9.09$ & $33.33 \pm 0.8$ \\
\hline \multicolumn{5}{|c|}{ Probability } \\
\hline \multicolumn{2}{|c|}{ Rabbit breed (B) } & 0.0921 & 0.0382 & 0.4286 \\
\hline \multicolumn{2}{|c|}{ Maca treatment $(\mathrm{T})$} & 0.8214 & 0.7892 & 0.1058 \\
\hline \multicolumn{2}{|c|}{ Interaction $(\mathrm{B} \times \mathrm{T})$} & 0.3827 & 0.4146 & 0.1750 \\
\hline
\end{tabular}

${ }^{A, b}$ Means with different letters within each column are significantly different $(P \leq 0.05)$.

Sig = Significant, $N s=$ Non-significant, $C=$ Control group, $T=$ Treatment group 


\section{Effect of rabbit breeds and maca treatment on FSH and LH hormone concentrations}

Results in Table 3 showed that the concentrations for both FSH and LH hormones were insignificantly influenced by rabbit breed or maca treatment.

The obtained findings indicated that the concentrations both hormones were insignificantly influenced by maca treatment. These findings agree with those of Nicole et al., (2008) who found that Maca did not exert an estrogenic effect in postmenopausal women, as indicated by the lake of change in plasma estradiol, FSH and LH concentrations. In addition to, Meissner et al., (2006b), reported that Maca increased serum levels of FSH for women. These findings are not agreement with Uchiyama et al., (2013), reported that maca supplementation insignificantly enhanced LH serum levels during pulsate phase in female rates. They attributed that the maca supplementation promotes ovulation trough pituitary function of the hypothalamus pituitary gonad axis. Also, the results of José et al., (2017) showed that the use of traditional maca play an important role to enhance fertility by enhance luteinizing hormone (LH) concentration levels in women. In addition to , Meissner et al., (2005), found that maca, increased LH hormone serum leves in early postmenopausal women. While the same authors reported that Maca reduced FSH levels after Maca treatment for 12 weeks in a cohort of early postmenopausal women. Contrarily, Yongzhong Zhang et al., (2014) found that long-term treatment with maca modulated hormone levels in ovariectomized rats, through decreasing FSH levels.

Effect of the interaction, no significant effect due to the interaction between rabbit breed and maca treatment on luteninzing hormone and follicle stimulating hormone concentrations.

\section{Effect of rabbit breeds and maca treatment on estrogen and progesterone hormone concentrations:}

The results of Table (3), indicated that the highest significantly $(\mathrm{P}<0.05)$ value of estrogen hormone concentration was recorded in NZW Does, followed by V-line, while the lowest one was obtained in Bouscat rabbit Does. Progesterone hormone concentration was insignificantly influenced by rabbit breed. The increased of estrogen concentration could be attributed to improved FSH hormone concentration for NZW compared with V-line rabbit Does.

Table (3). Hormonal estimates of rabbit does affected by line, treatment and their interaction $(\mathbf{L S M} \pm \mathbf{S E})$.

\begin{tabular}{|c|c|c|c|c|}
\hline Items & $\begin{array}{l}\mathrm{LH} \\
(\mathrm{MIU} / \mathrm{ML})\end{array}$ & $\begin{array}{l}\text { FSH } \\
(\mathrm{MIU} / \mathrm{ML})\end{array}$ & $\begin{array}{l}\text { Estrogen } \\
(\mathrm{Pg} / \mathrm{ml})\end{array}$ & $\begin{array}{l}\text { Progesterone } \\
(\mathrm{ng} / \mathrm{ml})\end{array}$ \\
\hline \multicolumn{5}{|c|}{ Effect of rabbit breed (B) } \\
\hline V-line & $2.10 \pm 0.1$ & $1.38 \pm 0.1$ & $57.96^{\mathrm{b}} \pm 2.3$ & $10.78 \pm 0.7$ \\
\hline NZW & $2.03 \pm 0.1$ & $1.43 \pm 0.1$ & $66.62^{\mathrm{a}} \pm 2.2$ & $10.02 \pm 0.7$ \\
\hline Bouscat & $2.10 \pm 0.1$ & $1.47 \pm 0.1$ & $53.19^{b} \pm 2.3$ & $9.34 \pm 0.8$ \\
\hline \multicolumn{5}{|c|}{ Effect of maca treatment $(\mathrm{T})$} \\
\hline Control & $2.12 \pm 0.1$ & $1.42 \pm 0.1$ & $57.74 \pm 1.8$ & $10.36 \pm 0.6$ \\
\hline Treatment & $2.03 \pm 0.1$ & $1.43 \pm 0.1$ & $60.78 \pm 1.9$ & $9.73 \pm 0.6$ \\
\hline \multicolumn{5}{|c|}{ Effect of interaction $(\mathrm{B} \times \mathrm{T})$} \\
\hline \multirow{2}{*}{ V-line } & $2.16 \pm 0.1$ & $1.36 \pm 0.1$ & $57.34 \pm 3.3$ & $9.87 \pm 1.0$ \\
\hline & $2.04 \pm 0.1$ & $1.41 \pm 0.1$ & $58.58 \pm 3.1$ & $11.69 \pm 0.9$ \\
\hline \multirow{2}{*}{ NZW } & $2.08 \pm 0.1$ & $1.43 \pm 0.1$ & $68.26 \pm 3.1$ & $11.38 \pm 0.9$ \\
\hline & $1.97 \pm 0.1$ & $1.44 \pm 0.1$ & $64.99 \pm 3.2$ & $8.67 \pm 1.0$ \\
\hline \multirow{2}{*}{ Bouscat } & $2.11 \pm 0.1$ & $1.49 \pm 0.1$ & $47.62 \pm 3.1$ & $9.83 \pm 1.1$ \\
\hline & $2.08 \pm 0.1$ & $1.36 \pm 0.1$ & $57.34 \pm 3.3$ & $8.84 \pm 1.2$ \\
\hline \multicolumn{5}{|l|}{ Probability } \\
\hline Breed (B) & 0.7756 & 0.6987 & 0.0002 & 0.4053 \\
\hline Treatment $(\mathrm{T})$ & 0.3199 & 0.9366 & 0.2456 & 0.4586 \\
\hline Interaction $(\mathrm{B} \times \mathrm{T})$ & 0.9073 & 0.9058 & 0.0738 & 0.0643 \\
\hline
\end{tabular}

These results are in agreement with those of Azoz and El-khaly (2005), who found that V-line exceeded Bouscat, does in progesterone concentrate without significant difference. In contrast, the same authors that the estradiol concentration was significantly higher in pregnant Bouscat Does than V-line ones. 


\section{El-Sheikh et al.}

The effect of Maca treatment, the obtained findings indicated that the estrogen hormone concentration of treated rabbit Does was numerically higher, while the progesterone hormone concentration was lower than that of the control. These results agreed with (Chacon, 1961), who claimed that alkaloids from Maca increased estrogen levels. Also, Manuel Gasco et al., (2008) suggested that estrogen like activity is not present in the extracts of different varieties of Maca. This is confirmed by the failure to increased uterine weight after treatment with Maca. Also, Hethir Rodriguez, (2007), found no significant effect of Maca on progesterone hormone in rabbits since it decrease progesterone levels compared with the control group. In contrast, Arletti et al., (1999), indicated that Maca increased progesterone levels in female mice because Maca contain Saponins, which play a very important role in sex hormones Saponins have been shown to normalize hormone secretion and have been used to treat sexual dysfunction.

The findings of Masami Oshima et al., (2003) indicated that maca treatment increased progesterone levels in female mice, which insignificantly on the embryo implantation rate in female mice.

Effect of the interaction, no significant effect due to the interaction between rabbit breed and maca treatment on estrogen and progesterone hormone concentrations.

\section{CONCLUSION}

The results of the NMPC (times), CR (\%) and GL (day) in different rabbit breed were not affected. NZW rabbit does have the highest value of estrogen hormone concentration, while the lowest value was recorded in Bouscat rabbit does.

Maca capsules on means of NMPC (times), CR (\%), GL (day) as well as LH, FSH and progesterone (P4) hormone concentrations. Estrogen hormone concentration was numerically increased. The progesterone hormone concentration in treated group was lower than the control, but not significantly different

\section{REFERENCES}

Arletti, R., Benelli, A., Cavazzuti, E., Scarpetta, G. and Berto-lini, A. (1999). Psychopharmacology 143: 15-19.

Azoz, A.A. and El-kholy, K.H. (2005). Blood metabolites and hormones of V-line and Bouscat female rabbits under Middle Egypt conditions. Egyption J. Rabbit Sci., 15: 131-142.

Azoz, A.A. and El-kholy, K.H. (2006). Reproductive performance and blood constituents of V-line and Bouscat female rabbits under Middle Egypt conditions. Egyption J. Rabbit Sci., 16 (1): 139-160.

Chacon Roldan G, et al. (1961). Estudio Fiftoquimico de Lepidium meyenii Walp. Thesis "Phytochemical studies of Lepidium meyenii Walp” Lima, Peru: Univ. Nac. San Marcos. 1961:1-43

Chacón de Popovici, G (1997). La importancia de Lepidium peruvianum ("Maca") en la alimentacion y salud del ser humano y animal 2,000 anos antes y desputes del Cristo y en el siglo XXI. Lima : Servivios Gráficos " ROMERO"

Documenta Geigy (1963). Tables Scientifiques 16th edn. Dep. Pharmaceutique Basel, Switzerland, PP. 51520.

Duncan, D. B. (1955). Multiple Ranges and Multiple F-Test. Biometrics, 11: 1- 42.

El-Hammady H.Y. and Abdel-Kareem A. A. A. (2015). A productive performance of rabbit does producing low number of weaning kids treated with some dried herbal seeds. Egypt. Poult. Sci. Vol (35) (II): (609625) $(2015$

Gad Allah, S. A. Z.; Abo Warda, M. A. and Samai Z. Meshreky (2005). Reproductive performance, litter traits and milk production of Baladi Red, V-line rabbits breeds and their crosser under Egyption environmental conditions. Egyption J. Rabbit Sci., 5: 45-6132.

Gonzales, G.F., Miranda, S., Nieto, J., Fernandez, G., Yucra, S., Rubio, J., Yi, P., Gasco, M., (2005). Red Maca (Lepidium meyenii) reduced prostate size in rats. Reproductive Biology and Endocrinology 3,5.

Hethir Rodriguez C.H., C.M.T. (2007). Maca, wonder herb for fertility . Natural Fertility INFO since 2007.

Kelly, G.S. (2001). Altern. Med. Rev. 6:293-302. 
Kropotov, A.V., Lisakovskaia, O. V. and Khotimchenko, Iu. S. (2001). Eksp. Klin. Farmokol. 64: 60-62 (in Russian with English summary).

José Manual, Zoraida Axtle and Julio Aviles, (2007). “Peruvian Maca and possible Impact on Fertility" J Nutr Health Food Eng 2007, 6 (5): 00217.

Manuel Gasco, Sandra Yucra, Julio Rubio, and Gustavo F Gonzales (2008). “ Lepidium meyenii (Maca) Did Not Alter Female Reproductive Parameters in Adult Intact Rats" . article in journal of Complementary and integrative Medicine. January 2008.

Marai, I. F. M.; Habeeb, A. A.M. and Gad, A.E., (2002). Rabbits productive, reproductive and physiological performance traits as affected by heat stress: a review. Livest. Prod. Sci. 78, 71-90.

Masami OSHIMA 1,2), Yeunhwa GU1) and Sekihito TSUKADA 1) (2003). Effects of Lepidium meyenii Walp and Jatropha macrantha on Blood Levels of Estrodiol-17ß, Progestrone, Testosterone and the Rate of Embryo Implantation in Mice". J. Vet. Med. Sci. 65(10): 1145-1146.

Meissner HO, Kapczynski W, Mscisz A, Lutomski J. (2005). Use of gelatinized Maca (Lepidium peruvianum) in early postmenopausal women - a pilot study. Int. J. Biomed Sci., 1:33-45.

Meissner HO1, Reich-Bilinska H, Mscisk A, Kedzia B.(2006). Therapeutic Effects of Pre-Gelatinized Maca (Lepidium Peruvianum Chacon) used as a Non-Hormonal Alternative to HRT in Perimenopausal womenclinical pilot Study. Int J Biomed Sci. 2006 Jun; 2 (2) 143-59.

Nicole A. Brooks, BSci (Hons)1, Gisela Wilcox, BMedSc (Hons), MD, FRACP, et al., (2008) “ Benefical effects of Lepidium meyenii (Maca) on psychological symptoms and measures of sexual dysfunction in postmenopausal women are not related to estrogen or androgen content". Menopause : The Journal of the North American Menopause Society. Vol. 15, No. 6, pp. 1157-1162. DOI: 10.1097/gme. 0b013181732953

Ruiz- Luna, A.C., Sandra, S.,Aspajo, N.J.Rubio, J., Gasco, M., and Gonzales, G.F. (2005). Lepidium meyenii (Maca) increases litter size in normal adult female mice. Reprod.Biol Endocrinol 5-3-2005; 3(1):16. View abstract.

SAS/ ETs 9.1 users Gide @ , SAS Institute - 2004

Uchiyama F, Jikyo T, Takeda R, Ogata M (2013). Lepidium meyenii (Maca) enhances the serum levels of luteinising hormone in female rats. J Ethnopharmacol 151 (2): 897-902.

Yongzhong Zhang, Longjiang Yu, Wenwen Jin, and Mingzhang Ao (2014). Effect of ethanolic extract of Lepidium meyenii Walp on serum hormone levels in ovariectomized rats. Indian j Pharmacol. 2014 JulAug; 46(4): 416-419.

Yoshida K, Ohta Y, Kawate N, Takahashi M, Inaba T, et al. (2017). Long-term feeding of hydroalcoholic extract powder of Lepidium meyenii (maca) enhances the steroidogenic ability of Leydig cells to alleviate its decline with ageing in male rats. Andrologia.

\section{تأثير التجريع بكبسولات الماكا على معدل الامساك والاداء التناسلى لأمهات الارانب}

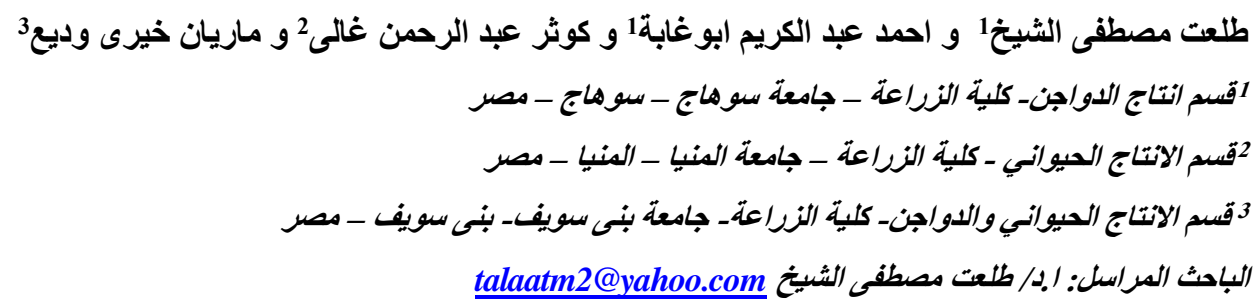

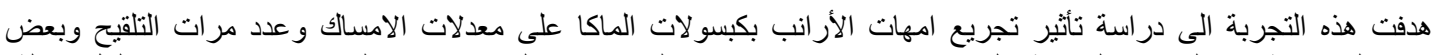

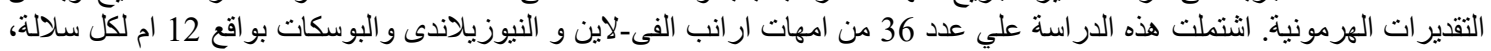

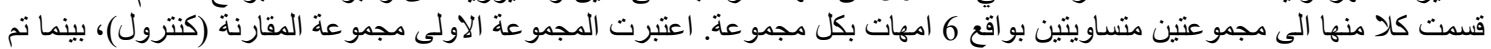

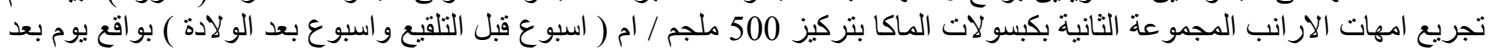

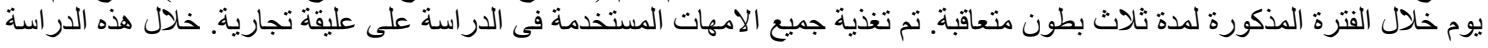




\section{El-Sheikh et al.}

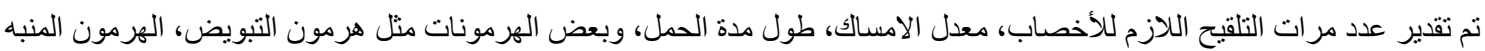

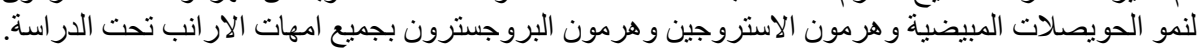

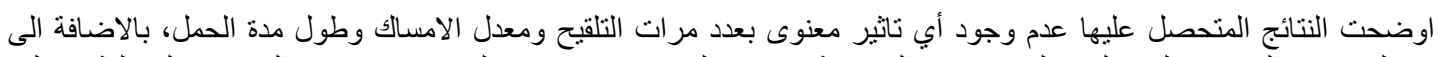

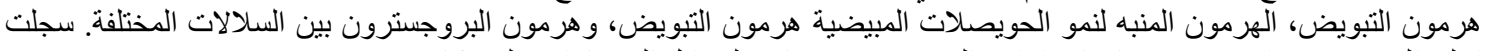

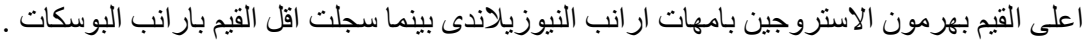

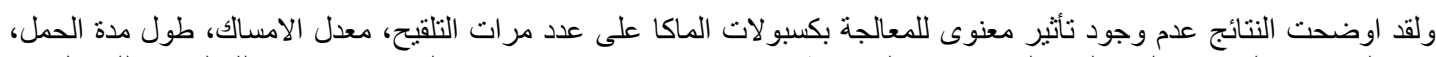

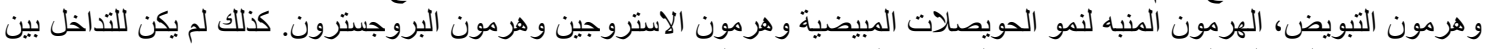

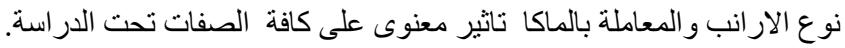

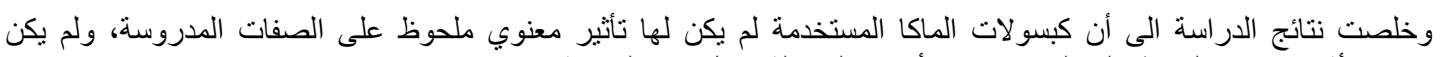

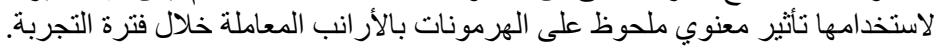

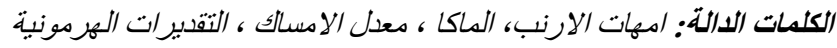

